\title{
The Use and Impact of Social Media during the 2011 Tunisian Revolution
}

\author{
Andrea Kavanaugh \\ Virginia Tech \\ Center for $\mathrm{HCl}$ \\ Blacksburg, VA USA \\ (540) 231-1806 \\ kavan@vt.edu \\ John C. Tedesco \\ Virginia Tech \\ Dept of Communication \\ Blacksburg, VA USA \\ (540) 231-3224 \\ tedesco@vt.edu
}

\author{
Steven D. Sheetz \\ Virginia Tech \\ Accounting \& Info Systems \\ Blacksburg, VA USA \\ (540) 231-2511 \\ sheetz@vt.edu
}

\author{
Yue Sun \\ Virginia Tech \\ School of Education \\ Blacksburg, VA USA \\ syuevt@gmail.com
}

\author{
Hamida Skandrani \\ University of Manouba \\ High Institute of Accounting \\ Manouba, Tunisia \\ (216) 71600705 \\ hamida.skandrani@gmail.com
}

\author{
Edward A. Fox \\ Virginia Tech \\ Dept of Computer Science \\ Blacksburg, VA USA \\ (540) 213-5113 \\ fox@vt.edu
}

\begin{abstract}
Citizen participation is a key factor in open government and a fundamental form of collective problem solving in democratic societies. Citizens need reliable information to support collective sense making and decision-making. During crises, such as political uprisings, reliable information sources are essential for citizens to stay informed and make sense of rapidly changing developments. In countries that exert control over media, citizens try to access alternative information sources, such as unfiltered Internet and social media. Using two rounds of online surveys with young adults in Tunisia, we examined the use of diverse media during the 2011 revolution. Our survey results show that higher perceptions of information reliability, along with the sharing of online information, lead to greater political information efficacy (PIE). Prior studies show higher PIE associated with greater democratic participation, which bodes well for collaborative decision-making in the nascent democracy in this North African state.
\end{abstract}

\section{CCS Concepts}

Human-centered computing->Human Computer Inter-action$>$ Empirical studies in collaborative and social computing.

\section{Author Keywords}

Social media; government; information sharing; political information efficacy; Tunisia; Arab uprising.

(C) 2016 Association for Computing Machinery. ACM acknowledges that this contribution was authored or co-authored by an employee, contractor or affiliate of a national government. As such, the Government retains a nonexclusive, royalty-free right to publish or reproduce this article, or to allow others to do so, for Government purposes only.

dg.o '16, June 08-10, 2016, Shanghai, China

(C) 2016 ACM. ISBN 978-1-4503-4339-8/16/06 ...\$15.00

DOI: http://dx.doi.org/10.1145/2912160.2912175

\section{INTRODUCTION}

On November 7, 1987, Tunisia's General Ben Ali led a successful coup against the aging President Bourguiba whose authoritarian regime reigned since independence from the French colonizers in 1956. Ben Ali's coup launched an optimistic period of political reform that also swept across the Middle East and North Africa in the late 1980s [2]. Algeria, Jordan, Yemen and Tunisia initiated political reforms that many observers and participants hoped would sustain democratic transitions. However, despite some initial reforms, within ten years, it was clear that the Ben Ali government was also deeply authoritarian. Methods for co-opting and manipulating the press, trade unions, and other organizations were similar to and sometimes worse than the Bourguiba regime [2].

Tunisia is the first country that initiated in December 2010 what became known as the Arab Spring, a series of cascading popular political movements that spread to Egypt, Libya, Bahrain, Yemen and Syria [21]. Protests and violent demonstrations originated in the rural town of Sidi Bouzid on December 18, 2010, and spread throughout Tunisia to its capital, Tunis, largely due to the participation of young well-educated adults [19], labor unions, and satellitedistributed news and videos broadcast by the Qatar-based Al-Jazeera Television Network [10, 13, 14, 29, 48]. For the most part, the Tunisian government-controlled media did not cover the uprising. After 29 days of violent street protests, on January 14, 2011, President Zine El Abidine Ben Ali resigned and went into exile in Saudi Arabia, ending his 23-year regime.

During political crises such as this, different actors seek to influence collective thinking and public participation. Democratic political response depends on a citizenry having reliable information on which to base discussion and collective decision-making.

Respondents' perceptions of the reliability of information sources are important to our study because prior research has 
shown that perceived information reliability predicts a greater sense of political information efficacy (PIE), that is, a person's belief that $\mathrm{s} / \mathrm{he}$ is well informed and capable of forming opinions and acting on political information. Our finding that sharing information with family and friends leads to a greater sense of PIE is not only a contribution to research on PIE, but also consistent with our earlier analyses of citizen participation, information reliability and sharing and PIE during the 2012 elections in Mexico[27].

Our findings build on several research areas in the digital government community, specifically, the use and impact of media on citizen participation, the sharing of information, and the use of media during government crises. We also contribute to our preliminary results in the 2012 Mexican elections and to the model proposed by Wang and Mark [46] which predicts that in regulated news environments, such as China, citizens will trust online news and citizens media more than government news, and will turn to their social networks and other citizens for alternative information sources.

The design of various social media in particular is important because it supports information sharing and discussion in users' social networks through social media such as Facebook (FB), which is the most commonly used Social Network Site (SNS) in Tunisia. Web 2.0 tools and capabilities, such as tagging, rating and recommending, facilitate dissemination of ideas and opinions that can lead to increased awareness of events, and collective decision-making and response, such as street demonstrations or voter turnout. This information sharing behavior among social network members seems to strengthen political information efficacy which is known to help increase democratic political participation. Our results showing a causal sequence from access to more reliable information to information sharing to increased PIE suggests that the nascent democratic tendencies emerging in Tunisia, unlike other Arab states in the 2011 uprisings, have an empirical basis for increasing democratic political participation in the face of reactionary counter-forces.

\section{THEORETICAL BACKGROUND}

Political participation theory emphasizes that an informed citizenry is fundamental to democracy [3, 31, 45]. It is through awareness and knowledge of issues and events that citizens are able to participate more fully in democratic decisionmaking. Seeking political information is itself a form of political participation. Citizens tend to participate more in civic life when they believe they have the political information they need to ask appropriate questions, form opinions and take action. This sense of feeling well informed about politics -- political information efficacy-- is a known predictor of engagement in democratic processes, such as, information sharing, discussion and consensus building [24].

Reliable information is posted content that users consider accurate, factual, trustworthy and relatively unbiased. Having access to reliable information for sense making and collective action is essential for citizen participation at any time, but it is especially important during political upheaval or revolution, so that citizens and organizations can interpret and respond to rapidly changing conditions $[1,22,40]$. Information quality or reliability is based on the perceived credibility of the information source and consequently on the satisfaction of users' need to stay informed.
Access to reliable information is fundamental to democratic political participation whether a country has a well-established democratic government or is struggling towards more democratic processes and institution building as it emerges from an authoritarian regime [11]. Such public access relies on, among other factors, a free press, which helps to educate and inform the public and foster debate.

In established democracies, traditional broadcast media, such as newspapers, radio and television, have played a critical role in informing the public. In authoritarian regimes, these traditional mass media have been highly restricted through licensing and censorship [5, 16]. This authoritarian model of the press is well understood and has operated in many dictatorial states for decades following independence from colonial powers [38].

\subsection{Media Use during Political Crises}

The advent of private satellite broadcast systems, such as Al-Jazeera and the Middle East Broadcasting Center (of which Al-Arabiya is a part), as well as the Internet and social media have loosened the grip of authoritarian regimes over since the 1980s [25, 40]. But during the 2010-11 uprising, the government in Tunisia (like that in Egypt) shut down or reduced bandwidth on Internet access intermittently, e.g., blocking access to FB and YouTube, and reducing bandwidth on cell networks in protest areas [43].

Social network sites (SNS), wikis, blogs, microblogs, and photo and video sharing websites (collectively referred to as social media) provide online platforms and software for users to more easily and widely share information with their social network of friends, family, acquaintances and local or distant groups to which they belong, as well as the larger general public [7, 33, 49]. Sharing information, opinions and ideas is made easier via information production tools (i.e., Web $2.0)$ that accommodate tagging, posting, rating and other user-generated content $[8,37,41]$.

The near universal ownership of cell phones and the use of phone apps in combination with Internet and social media have been fundamental to accessing information and sharing it. In 2011, at the time of the Tunisian revolution, there was over $100 \%(115.2 \%)$ penetration of cell phone ownership in Tunisia [23]. Citizens' use of all these information sources and devices was instrumental in accessing, creating and sharing information in Tunisia and across the region during the Arab Spring of 2011 [20, 30, 44, 48].

\subsection{Social Networks \& Information Sharing}

We also draw on social network theory in our analysis. Tunisia is recognized as a high contact culture [39], that is, a society with dense social networks and strong social ties (i.e., extended family and close friends who interact frequently and know each other well from multiple contexts). As a 'high contact culture' Tunisians get together regularly, and communicate by phone or online in between social gatherings.

Social network theory states that people rely on their social networks for aid (e.g., information) and emotional support [47]. In societies with authoritarian regimes, citizens tend to rely on each other to try to interpret news and information from mainstream sources, since censorship is common in the government-controlled mass media (e.g., TV, radio and print media) [1, 46]. We can expect that during a political crisis, such as the Tunisian 
revolution, people in a high contact culture will share information rapidly with each other, and in different ways (face-to-face, phone, online) and compare what they hear to to make sense of it $[6,26]$.

In a study of the use of blogs during the five years leading up to the Egyptian uprising in 2011, Wang and Mark [46] model citizens' preference for news from social media. That is, features of social media explain why citizens might trust it as a channel of news in a regime where the press is tightly controlled. Essentially, citizens trust each other more than government for information, so citizen media serve as alternative news sources. During the period of the study (20042011), blogs provided a medium for citizens to report events, commentary and criticism of institutionalized power as represented by government-controlled media in Egypt.

\subsection{Political Information Efficacy}

Political information efficacy or PIE [24, 32] is related to (but distinct from) internal political efficacy, the belief that one is competent to participate in politics in a broad sense (not just because one has adequate information). External political efficacy is also important in predicting participation; it is a person's belief that the government authorities are genuinely interested in and responsive to his or her needs and interests (whether individually or as an identity group, such as a minority, or just as a citizen of an authoritarian regime).

Our goal is to establish by empirical tests whether there are significant differences in subjects' use and evaluation of different information sources during this political crisis. Given prior research, although empirical studies are limited, we expect significant differences in the use and evaluation of government-controlled versus more independent media. More importantly, within the more independent media (i.e., Internet and social media), we seek to determine empirically whether there are significant differences among these information sources in terms of use and perceptions of reliability.

We further test for information sharing behavior, since prior studies suggest that in countries with authoritarian regimes and tight controls over the press, we can expect that citizens are likely to turn to each other for information. The design of Internet and social media enable fairly easy information sharing among family, friends and the larger public. One potential social impact of sharing reliable information with friends and family under these kinds of difficult circumstances (i.e., protests, government-controlled press) is a greater feeling among citizens of being politically informed and knowledgeable. Given that PIE is an important predictor of higher levels of political participation, we test it in this paper for its potential role in facilitating democracy in Tunisia.

Before turning to our Methods and Results, we summarize briefly the larger context of the media systems and national penetration in Tunisia at the time of the uprising.

\section{TUNISIA AND ITS MEDIA LANDSCAPE}

Tunisia is a small, upper middle-income country in North Africa with a population of about 10.5 million in 2010 , at the outset of the uprising. It is a former French colony whose predominant languages are French and Arabic. Tunisia's economy is highly dependent on foreign tourism. According to World Bank indicators [23] adult literacy in 2011 was fairly high at 79\%; GDP per capita in current US dollars was $\$ 4,305$ in 2011 ; total unemployment just before the uprising was about $13 \%$ and rose to $18 \%$ a year later, with the loss of some foreign investment and tourism. Youth unemployment (ages 15-24) as a percentage of total labor force was high (29\%) and has been especially high for educated youth which is one of the motivations for their participation in the uprising [12].

\subsection{TV and Radio Broadcasting}

Until 2003, all national radio and TV broadcasting was owned and controlled by the Tunisian state, and therefore, reflected favorable views of the government. Liberalization of the media, initiated in 2003 , permitted the entry of numerous private sector actors, but did not eliminate the government control or censorship of these media [18].

The government-owned TV network operating before and during the uprising, La Télévision Nationale (Tunisie 7 and Canal 21), offered news, sports, films and culture. News programs promulgated government views. In 2005 the first private TV station, Hannibal TV, began broadcasting. This station was owned by Larbi Nasra, a businessman, almost unknown in the media sector, who benefitted from some privileges (including financial support) due to close ties with the authorities [9]. After the uprising, the Hannibal TV owner was arrested and accused of trying to spread disinformation in order to bring the country into chaos and hasten the return of President Ben Ali [9].

In 2009 another private channel, Nessma TV, began broadcasting a regular program. Nessma is partly owned by Italian media tycoon and former Prime Minister Silvio Berlusconi in partnership with the Karoui brothers, important Tunisian businessmen. Nesma TV largely focused on entertainment, sports and reality shows before the uprising, but presented some debates on social issues while avoiding red lines that the Ben Ali regime had in place [17]. Before the uprising, the private TV Stations Hannibal and Nessma operated throughout the country, but were not fully independent in so far as they were officially forbidden from reporting on politics.

Al-Jazeera TV, established in 1996 in Qatar as a pan-Arab network, has been praised for circumventing censorship and contributing to the relatively free exchange of information in the Arab world $[4,15]$. But as the Egyptian uprising unfolded during 2011, and the Muslim Brotherhood came to power through elections, Al-Jazeera's coverage was deemed by many in the Middle East to be biased in favor of the Muslim Brotherhood despite increasing encroachment of executive power over the legislative and judiciary.

Al Arabiya TV, sponsored by the Saudi royal family, launched in 2002, headquartered in Dubai, is part of the Middle East Broadcasting Center (MBC) [28]. While Al-Arabiya news coverage is not highly critical of Saudi Arabia, it seeks to play a more moderate role than Al Jazeera, that is, less emphasis on politics and any Arab regional tensions and conflict [34].

Radio broadcasting followed a similar pattern. With liberalization in 2003, the first private radio station appeared, Radio Mosaique FM, followed in 2005, by Radio Jawhara. In 2007, the country's first Islamic radio station launched, Radio Zitouna. In 2010 two more private radio stations obtained licenses to broadcast, Shems FM and Express FM, however these were closely affiliated with the regime. Before the uprising, President Ben Ali's daughter directed Shems FM, and Mourad Guediche, the son of the President's private doctor, directed Express FM [17]. 


\subsection{Print Media: Newspapers, Magazines}

There were many daily newspapers and magazines in Tunisia before the revolution; private groups and individuals owned most of them. However, public and private newspapers were under the control of the government through the authorization of licenses, and by direct censorship and self-censorship. After Jaunary 14, 2011 and the confiscation of President Ben Ali and his family's assets, Assabah came under state control. The 2011 revolution gave rise to more than $30 \mathrm{TV}$ and radio channels, new newspapers and magazines and online news sites.

\subsection{Internet and Social Media Use}

Internet penetration in Tunisia at the time of the uprising (end of 2010 , early 2011 ) was $36.8 \%$, rising to $43.8 \%$ by 2013 when we ran our surveys [23]. Facebook penetration rose from $17.6 \%$ in early 2011 to $33.9 \%$ in 2013; Twitter penetration has stayed about the same since the uprising when it was less than $1 \%(0.34 \%)$ [36]. Even before the uprising, citizens with Internet access could seek out a variety of Internet-based news sources, including websites of print newspapers, such as La Press (lapresse.tn), Le Temps (www.letemps.com.tn), and Le Maghreb (lemaghreb.tn) and TV stations, such as Al Jazeera (Aljazeera.net) and CNN (cnn.com).

Video and photo-sharing websites and the social network site (SNS) FB appeared to play key roles in spreading information in Tunisia at the outset of the unrest in response to the suicide by self-immolation of a young street vendor in the town of Sidi Bouzid [48]. The Tunisian government blocked access to the Internet in early December, thereby restricting use of FB, Twitter and YouTube (until Jan 13, 2011). Subsequently, President Ben Ali tried to calm the population by promising to unblock Internet access. Nonetheless, through a combination of media, including, Al-Jazeera TV, cell phones, Internet websites and social media, citizens became aware of events and contacted others to share information, ideas and opinions, and to coordinate a series of collective actions, such as street demonstrations. The Tunisian uprising gave birth to new online news sources, and opened up access to some blocked or filtered websites, e.g. www.nawaat.org, YouTube.com and dailymotion.com.

Young, educated Tunisians were credited with being an important influence in the uprising in 2011, along with their use of social media, especially FB. The relatively independent Arab regional satellite TV broadcasting network, Al Jazeera, was also credited with carrying timely and reliable information and video footage of protests and demonstrations that rocked North Africa at the time (most notably, Egypt, Libya and Tunisia).

\section{METHODS}

Based on these theoretical arguments and findings from prior research, we tested the following set of related hypotheses: young, educated Tunisians, such as those in our sample will: 1) use more heavily and rate as more reliable information sources that are less government-controlled; and 2) share regularly with family and friends information obtained from media that are less controlled by government. We also test the prediction that subjects who report using more independent sources and who share information regularly with family and friends will experience a greater sense of PIE.

\subsection{Survey Sample}

We designed and administered an online survey to an opportunity sample of university students in courses taught by co-author Skandrani at the University of Tunis, High Institute for Management (Haut Institut de Gestion). Most courses in this institute are taught in French, so we translated the survey into French. We administered the first round in February 2013 and the second round of the same survey in November 2013. This is admittedly a long time after the events, which means respondents' recollections may not have been as accurate. This is a weakness of our study.

For Round 1 Prof. Skandrani invited an estimated 280 students to participate. She recruited them in several ways: in class, via FB groups, class Google groups or personal invitation by email or via private message on FB. For Round 2 she invited a similar sample in the same manner from an estimated 340 students in the same programs. There were multiple sections to the online survey and it took about 20 minutes to complete.

\subsection{Survey Instrument}

Apart from face-to-face and phone communication with family and friends, the types of media we asked about fell into two broad areas: more government-controlled media and more independent media.

Media Use: Information Sources and Frequency of Use: Among government-controlled media (which were traditional, mass media) we asked about TV and radio networks and print newspapers. For each of these information sources, we specified networks and newspapers by name. We asked which of the listed items they watched/listened to/read most often to obtain information about political developments during the uprising. The specific TV and radio networks we asked about are those noted above and 'Other'. The specific newspapers we asked about are: Assabah, Essahafa, La Presse, Le Temps, Echourouk, Agence Tunis Afrique Press, and Other.

Among more independent media, we asked about use of Internet, SNS (e.g., FB), Twitter, photo and video sharing sites, blogs, and Internet communication services, such as Skype and Instant Messaging (IM). We also asked about cell phone use, and specific features, such as sending and/or receiving voice and text messages, sending and/or receiving photos or videos, and accessing the Internet.

Information Reliability: We asked respondents to rate the reliability of the government-controlled versus more independent sources they used to obtain information during the uprising. As with the 'Media Use' and 'Frequency of Use' questions we listed each type of source individually (e.g., Twitter, SNS, photosharing). We asked them to rate the reliability of each of these sources on a 4-point scale from: 0 (not at all reliable) to 4 (reliable most of the time).

Due to survey length concerns, for the reliability of TV, radio and newspapers, we did not list each station or newspaper by name again; rather, we asked them to rate the reliability of: 1) TV stations 2) radio stations, and 3) newspapers, that they used most often to obtain information about political developments during the uprising.

We asked several questions related to overall information availability with response categories on a 4-point Likert scale of agreement: 1) Overall, I was able to obtain the information I needed during the uprising, 2) Overall, I was able to obtain the information that I wanted during the uprising, 3) In general, I felt like I knew what was going on during the uprising, and 4) The 
information that I obtained during the uprising was not reliable (reverse coded) for the analyses. It is acceptable for researchers to use a 4-point scale when want to require respondents to show which way they might be leaning on a question [35, 42].

Social Network Sharing of Online Information Sources: To measure the extent of information sharing by respondents with their social networks, we asked (with a 4-point agreement scale) whether respondent's family and friends regularly shared online information about the uprising with the respondent. We also asked (with 4-point agreement scale) whether the respondent regularly shared online information about the uprising with friends and family.

We asked respondents to think about older members of their social networks (older than 30 years), such as parents, grandparents, aunts, uncles and older family friends and whether they use Internet, SNS/FB, blogs, photo/video sharing sites or cell phones) to obtain political information during the uprising. These were individual items with yes/no response categories. We asked the same questions about respondents' younger (under 30 years old) friends and family (e.g., siblings, cousins, age cohort friends).

Political Information Efficacy: There are four standard questions for this construct, which we adapted slightly for this context, as follows: 1) I consider myself well qualified to participate in politics of the current Tunisian government; 2) I think that I am better informed about Tunisian politics and government than most people; 3) I feel that I have a pretty good understanding of the important political issues facing Tunisia; and 4) If a friend asked me about the Tunisian elections and related political events, I feel I would have enough information to help my friend figure out whom to vote for.

We asked three standard questions measuring internal and external political efficacy [3]. Response categories were a 4-point agreement scale); these are: 1) Since the first government of Mouhamed Ghannouchi, I feel that sometimes politics and government seem so complicated that persons like me can't truly understand what's going on; 2) I don't think officials in the current Tunisian government care much what people like me think; and 3) There are plenty of ways for people like me to have a say in what the current Tunisian government does.

Demographics: We asked about basic demographics, including age, gender, highest level of education completed, occupation (e.g., student) and marital status.

\subsection{Data Analyses}

We analyzed the results with standard statistical techniques, including correlations, factor analysis and regressions, using SPSS software. For the factor analyses, we used Principal Component Analysis extraction method, and Varimax with Kaiser Normalization rotation method.

\section{RESULTS}

For Round 1, we had 183 respondents who completed most, but not all, of the online survey; 80 respondents completed the survey fully. This is a response rate of $65 \%$ and $27 \%$, respectively. For Round 2, we had 130 respondents who completed most, but not all of the survey; 70 respondents completed the survey fully. This is a response rate of $38 \%$ and $21 \%$, respectively.

There were no significant differences on any of the variables between Round 1 and 2, except for the questions regarding change in use of different media since the uprising. We do not address these questions in this paper. Therefore, we combined responses from Rounds 1 and 2 to provide higher numbers $(\mathrm{N}=313)$ of responses for the tests we ran.

Of the 313 respondents, $61 \%$ were female and $89 \%$ were single. Participants were highly educated, with $43 \%$ completing Masters, $40 \%$ with bachelor degrees, and $17 \%$ diplomas from technical, commercial or industrial schools. Forty-nine percent of participants reported their age. Age ranged from 20 to 45 years old; the mean age was 24 years. Eighty percent of participants reported they used French to interact on the Internet, 34\% used Arabic, 40\% used Franco-Arabic, and 6\% used other languages.

\subsection{Media Use during the Uprising}

The vast majority of respondents $(84 \%)$ reported talking face-to-face and about half $(51.6 \%)$ by phone with family and friends to obtain information about political developments during the uprising. Almost all respondents (98.7\%) reported they had cell phones, and half reported that they had smart phones.

The most commonly watched TV station was Al Jazeera (75.6\%), followed distantly by National Television channels (40.2\%) and Al Arabiya (37\%). Table 1 lists the stations in descending order of popularity. The total percentages add to more than $100 \%$ because we asked subjects to check all stations that they watched most often to get information about political developments during the uprising.

\begin{tabular}{|l|c|}
\hline TV Station & Percent Who Watched \\
\hline A1 Jazeera & $75.6 \%$ \\
\hline TV Nationale & 40.2 \\
\hline Al Arabiya & 37.0 \\
\hline Nessma & 33.1 \\
\hline Other & 29.9 \\
\hline Hannibal & 25.4 \\
\hline BBC Arabic & 7.7 \\
\hline
\end{tabular}

Table 1. TV Stations Watched Most Often

The category 'Other' was open-ended; respondents listed most frequently France $24(\mathrm{~N}=26)$ and Canal $1(\mathrm{~N}=18)$. France 24 is a Paris-based news network broadcasting in English, French and Arabic, generally considered less biased than Tunisiangovernment controlled media, such as Canal 1. Canal 1 is the second Tunisian government-owned 'TV Nationale' station. Factor analysis shows that the government-controlled channels loaded together (TV Nationale, Hannibal and Nessma), as did the more neutral stations (Al Arabiya and BBC Arabic); Al Jazeera was a factor unto itself.

Most respondents (73.6\%) reported they did not read any newspapers. Of the minority who did, they predominantly read La Presse (25\%) and Echourouk (9.9\%). Totals are higher than $100 \%$ because we asked respondents to check all the papers they read most often for political information. The most popular radio station was Mosaique FM, listened to by almost two-thirds of 
respondents (63.8\%), followed by a distant second (18.2\%) Shems FM.

The vast majority of respondents used the Internet (99.2\%) to get political information during the uprising ( $93.8 \%$ used it on a daily basis; $85.4 \%$ used it several times a day). A vast majority (98.7\%) also reported using SNS/FB; $96.6 \%$ reported using SNS daily; $89.4 \%$ used it several times a day. A majority (81.4\%) reported using some kind of Internet communication service, such as Skype, MSN, or Yahoo messenger; $56.9 \%$ used them daily. Only a quarter $(25 \%)$ of respondents used Twitter; a small, active subset (16.9\%) used Twitter daily.

The majority $(79.1 \%)$ reported using photo/video-sharing sites, such as Flickr and YouTube, at least daily (60.7\% several times a day). Only $6 \%$ of respondents were not using these sites at all. Most (60.7\%) read or wrote blogs about the uprising; $29.1 \%$ read or wrote blogs daily.

\subsection{Reliability of Information Sources}

Face-to-face communication had a very high reliability rating (not significantly different from photo/video sharing sites with the highest mean). Other online sources had high reliability mean scores, including FB, Internet news sites and the Internet generally (Table 2).

\begin{tabular}{|l|c|c|}
\hline $\begin{array}{l}\text { Information } \\
\text { Source }\end{array}$ & $\begin{array}{c}\text { Mean } \\
\text { Reliability }\end{array}$ & $\begin{array}{c}\text { Standard } \\
\text { Deviation }\end{array}$ \\
\hline Video sharing Site & 1.81 & .86 \\
\hline Facebook & 1.79 & .82 \\
\hline Face-to-Face & 1.73 & .79 \\
\hline Internet News & 1.59 & .76 \\
\hline Internet general & 1.46 & .85 \\
\hline TV & 1.38 & .88 \\
\hline Twitter & 1.36 & .98 \\
\hline Radio & 1.33 & .99 \\
\hline TV Talk Shows & 1.19 & .99 \\
\hline Newspapers & 1.01 & .93 \\
\hline Government & 0.90 & 1.01 \\
\hline
\end{tabular}

Table 2. Mean Reliability of Information Sources

At the lower half of the list in descending order, were TV, Radio, TV Talk Shows, Newspapers and Government sources. Twitter is in the lower group, but it is not significantly lower than these items. It is significantly lower than other online sources, but significantly higher than government sources (see Table 4). In reporting the reliability mean for Twitter, we controlled for use of Twitter.

For the reliability means for $\mathrm{TV}$, we did not ask respondents to give a reliability score for TV stations individually, as noted earlier. Rather in one question we asked them to rate the reliability of the TV channel(s) they watched most often. To try to rank order the TV stations by perceived reliability with statistical validity, we had to select only those cases in which a respondent watched only one station. Then we could compare these respondents' answers for the single item question on TV reliability.
The number of respondents who reported watching only one TV station is low, so, we cannot accept statistical tests. For example, there was only a small number of cases ( 25 and 9, respectively) to compare the mean differences between perceived reliability of $\mathrm{Al}$ Jazeera (1.56) and National TV (0.89), but it does approach significance, $\mathrm{p}<=.09$. These scores can only suggest a trend.

The variables (frequency of TV watching) are binary (yes, no or 1, 0 ), so we could conduct the principal components analysis for categorical data (CATPCA) to further compare them with each other. We ran a factor analysis on the TV stations in order to test for groupings based on the extent of government control. Table 3 shows that the government-controlled Tunisian stations (TV Nationale, Hannibal, and Nessma) loaded together on the first factor. The government-controlled regional stations (Al Arabiya and BBC Arabic) loaded together on the second factor. The most independent TV network, Al Jazeera, loaded as a third factor unto itself.

\begin{tabular}{|l|c|c|c|}
\hline \multirow{2}{*}{} & \multicolumn{3}{|c|}{ Component } \\
\cline { 2 - 4 } & $\mathbf{1}$ & $\mathbf{2}$ & $\mathbf{3}$ \\
\hline TV Nationale & $\mathbf{. 6 2 9}$ & -0.95 & -0.43 \\
\hline Nessma & $\mathbf{. 7 3 5}$ & -.066 & -.192 \\
\hline & $\mathbf{. 7 8 1}$ & .139 & -.023 \\
\hline Al Arabiya & & & \\
\hline BBC Arabic & .162 & $\mathbf{. 8 7 1}$ & .062 \\
\hline & -.371 & $\mathbf{. 5 9 4}$ & -.309 \\
\hline Al Jazeera & & & \\
\hline
\end{tabular}

Table 3. Factor Analysis: TV Stations Most Watched

To compare the reliability means shown in Table 2, we conducted paired-samples t-tests (see Table 4) comparing all of the information sources with each other. Comparisons in Table 4 read from row to column, so that a positive mean difference indicates that the row variable has greater value than the column variable. Conversely, a negative mean difference indicates that the row variable has a lesser value than the column variable.

To test whether perceptions of reliability grouped together based on more or less government control over information sources, we conducted factor analysis on these variables. These variables generally loaded into two factors, with the government-controlled sources (variables) in one factor and the more independent sources loading in a second factor (Table $5)$.

The more independent sources of information, including photo/video-sharing sites, FB, general Internet sites (not SNS), and Internet News sites, group together with Face-toFace communication (Table 5). Government-controlled media (Radio, Newspapers, TV and Government sources) form a second factor. A third factor contained both Twitter and TV Talk Shows with 'Other' sources, but it is not clear why these items load together, except that they were all rated low. 


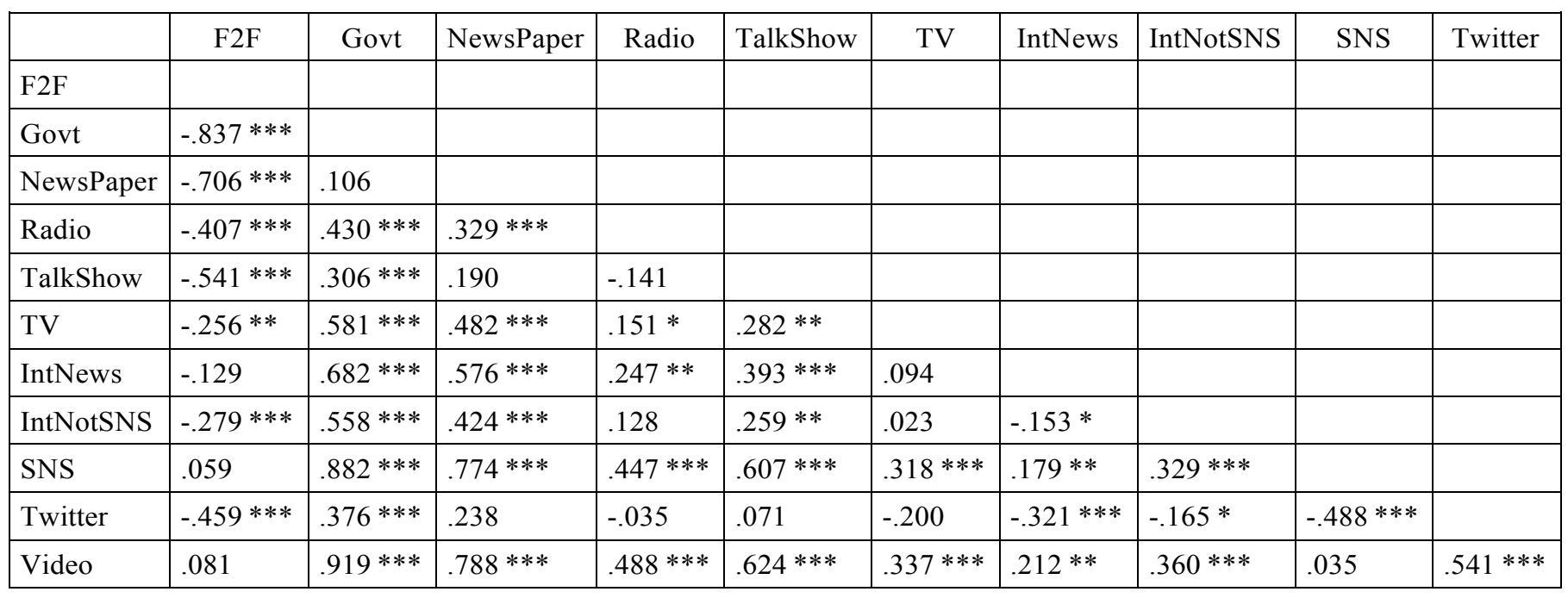

Table 4: T-test comparisons of mean perceived reliability for media sources (mean difference and significance)

\begin{tabular}{|l|c|c|}
\hline \multirow{2}{*}{} & \multicolumn{2}{|c|}{ Component } \\
\cline { 2 - 3 } & $\mathbf{1}$ & $\mathbf{2}$ \\
\hline Photo/video Sites & $\mathbf{. 8 2 6}$ & -.026 \\
\hline Face-to-Face & $\mathbf{. 7 6 2}$ & .238 \\
\hline SNS (Facebook) & $\mathbf{. 7 6 0}$ & .018 \\
\hline Internet Not SNS & $\mathbf{. 6 5 5}$ & .067 \\
\hline Internet News & $\mathbf{. 6 2 1}$ & .369 \\
\hline & & \\
\hline Radio & .232 & $\mathbf{. 8 4 8}$ \\
\hline Newspapers & -.094 & $\mathbf{. 7 8 6}$ \\
\hline TV & .331 & $\mathbf{. 7 2 7}$ \\
\hline Government & -.062 & $\mathbf{. 6 7 1}$ \\
\hline
\end{tabular}

Table 5. Factor Analysis: Source Reliability

Finally, to test which information sources contributed most to respondents' perceptions of the overall reliability of information obtained during the uprising, we computed three scales: 1) overall reliability of information obtained, 2) reliability of independent media used, and 3) reliability of government-controlled media used. Our Independent Media Reliability scale (Cronbach alpha $=.80$ ) and Governmentcontrolled Media Reliability scale (Cronbach alpha $=.80)$ both have values above the acceptable cut off of .70 for this measure. Our Overall Reliability scale has a Cronbach Alpha of .69, which we deemed acceptable. The Overall Reliability scale is based on the average of agreement responses to three general statements: 1) Predictions I received during the uprising were reliable, 2) Interpretations I received about events during the uprising were reliable, and 3) Overall, the information I was able to obtain during the uprising was accurate.
To determine which specific media contribute the most to perceptions of overall information reliability we regressed the individual reliability scores for each media (e.g., TV, Social Network Sites, Newspapers) on the Overall Reliability scale. Only SNS/FB $(\mathrm{p}<.01)$ and Internet News sites $(\mathrm{p}<.10)$ are significant predictors of perceptions of Overall Reliability. FB (beta $=.383$ ) in fact, contributes more than Internet News sites (beta $=.264)$.

\subsection{Information Sharing Behavior}

Most respondents $(77.9 \%)$ reported that during the uprising they regularly shared information about the uprising that they had obtained from the Internet (including FB YouTube or Twitter) with their family members and friends. A similar majority $(81 \%)$ reported that during the uprising their family and friends regularly shared information related to the uprising that they had obtained from the Internet with them.

In considering independent media use by older members of their social networks (older than 30 years), such as parents, grandparents, aunts, uncles and older family friends, almost all respondents answered "yes" to all items, that is, they use Internet, social network sites/FB, blogs, photo/video sharing sites or cell phones. Respondents reported the same about younger members of their social networks (e.g., siblings, cousins, age cohort friends) and their use of each of these media.

\subsection{Political Information Efficacy}

We conducted a factor analysis to test our four-item construct measuring political information efficacy (PIE). These four items did load together as one factor (Cronbach alpha=.75). Two additional items we used to measure internal and external political efficacy loaded together; these are agreement scales on: 1) Since the first government of Mohammed Ghannouchi, I feel that sometimes politics and government seem so complicated that persons like me can't truly understand what's going on; and 2) I don't think officials in the current Tunisian government care much what people like me think (reverse coded). A final item in this group did not load with any other factors: There are plenty of 
ways for people like me to have a say in what the current Tunisian government does.

Using regression analyses we tested different media sources for their prediction of PIE. We find that frequency of Internet use and frequency of FB use are significant predictors of PIE (adj. R Square $=.25, \mathrm{p}<.05$ ). Overall reliability of media sources is also a significant predictor of PIE (adj. $R$ Square $=.404, \mathrm{p}<.01$ ).

A final set of variables affecting PIE is the sharing of online information with one's social network. We conducted an independent samples t-test of mean differences (Table 6) to test for information sharing among social network members and PIE.

\begin{tabular}{|l|l|l|l|}
\hline & t & Sig. & Mean Diff. \\
\hline PIE Feel Informed & 2.099 & .041 & 0.814 \\
\hline PIE Know Issues & 2.792 & .008 & 1.162 \\
\hline PIE Advise Friend & 2.647 & .011 & 1.033 \\
\hline PIE Qualified & & NS & \\
\hline
\end{tabular}

Table 6. Information Sharing and PIE

We find that three of the four measures of PIE are significantly higher among respondents who shared online information with family and friends and whose family and friends shared online information about the uprising with the respondent.

\section{DISCUSSION}

Prior research on information seeking during crises in authoritarian regimes suggests that citizens will seek information from independent media more frequently than from government-controlled media. We provide additional empirical evidence testing these claims, and proceed from there to examine and differentiate the use of more independent media (Al Jazeera TV, Internet and social media). We suspect our respondents watched government-controlled TV, to the small extent that they did, in order to obtain multiple perspectives (including the government's) of events to compare it with coverage by more independent media.

The high reliability rating for video-sharing websites, such as YouTube, could be due to respondents' expectation that video shown on government-controlled TV would have been selected or edited to minimize public outrage. The high reliability perceived for SNS/FB reflects the trust that citizens have of information obtained through their social networks, whether sitting around the dinner table or online. The high reliability perceived for Internet news websites we suspect was due to the possible use of the Al Jazeera news website.

With regard to respondents' low perceived reliability of Twitter, it is possible that the tweets had contradictory information or other ambiguous or uninformative content (e.g., expressions of support rather than information). Twitter penetration among our respondents (and the general Tunisian population) was - and continues to be - very low.

Political uprisings are crises for both government and citizens. Our findings contribute to studies on the use of social media during crises by providing empirical evidence about the communication behavior of young, educated
Tunisians during the 2011 revolution. Our finding that young, educated Tunisians' prefer SNS/FB, photo/video sharing sites and news websites, such as Al Jazeera, over other Internet or social media sources (e.g., Twitter), underscores the importance of social trust in the prioritization of different independent media sources during crises.

\section{CONCLUSIONS}

Through two rounds of surveys, we examined the use of different information sources by an opportunity sample of educated, young adult Tunisians and their informationshared behavior with members of their social networks during the revolution (mid-December 2010 to mid-January 2011). We investigated their perceptions of the reliability of information they obtained from government-controlled media versus more independent media. Finally, we examined the impact of media use and sharing on respondents' political information efficacy, i.e., their sense of being well informed and qualified to participate in democratic processes and decisionmaking.

We find that the majority of respondents primarily used face-to-face communication (and phone) with family and friends, as well as relatively independent media, such as Internet-based sources, including social media, to obtain information about political developments. Among traditional broadcast media (e.g., newspapers, radio, TV), the majority of respondents used primarily Qatar-based Al Jazeera TV. Very few reported they used government-controlled media, such as newspapers, radio and other TV networks.

The (government-owned) National Television of Tunisia was a distant second after Al Jazeera among the TV stations that our respondents reported they watched most often during the uprising for news about political developments.

Respondents reported that they perceived independent media (Al Jazeera, Internet, including social media) to be more reliable than government-controlled media. Within Internet and social media sources, respondents rated photo/videosharing sites, Internet-based news sources and Facebook (FB) the most reliable. It is likely that respondents were using the online website of Al- Jazeera as well as viewing the TV broadcasts, which would have boosted their reporting of the reliability of Internet news sites. Twitter was perceived as the least reliable among socialmediasources of information.

Greater information reliability predicts higher levels of political information efficacy (PIE), i.e., a person's feeling of being politically informed and knowledgeable. Thus, our results indicate that an important impact of Internet and social media use is increases in users' sense of PIE. More importantly, our results indicate that sharing online information regularly with social network members (e.g., family and friends) predicts higher levels of PIE. Higher levels of PIE are associated in many studies with higher levels of political participation. Thus, our findings suggest that in these critical situations, social media access and use leads to more reliable information, more information sharing, higher levels of efficacy and more political participation.

Our results contribute to the small body of empirical research on the use of more independent media by educated, young adults and their role in political change in the Middle East. 
These findings further elaborate on the social impact of media use on young citizens' sense of being politically informed and knowledgeable during conditions of crisis and uncertainty. Our findings bode well for the 2010-11 struggle for democratic reforms that failed in 1987.

\section{ACKNOWLEDGMENTS}

We would like to thank our study participants in both survey rounds and our collaborators on this project, Donald Shoemaker and Sehl Mellouli. We also thank graduate research assistants Mohamed Magdy Farag and Sunshin Lee. We are grateful to the National Science Foundation (NSF) for its support of the IDEAL project of which this work is part (IIS-1319578). Any opinions, conclusions, and findings or recommendations expressed here are those of the authors and do not necessarily reflect the views of NSF.

\section{REFERENCES}

[1] Al-Ani, B., Mark, G., Chung, J. and Jones, J. 2012. The Egyptian Blogosphere: A counter-narrative of the revolution. In Proceedings of the 2012 Conference on Computer Supported Cooperative Work (CSCW'12) (Seattle, WA, February 11-13, 2012). ACM, New York, NY, 17-26.

[2] Alexander, C. Back from the Democratic Brink: Authoritarianism and Civil Society in Tunisia. Middle East Report, 27, 4 (1997), 34-38.

[3] Almond, G. A. and Verba, S. 1963 The Civic Culture: Political attitudes and democracy in five nations. Princeton University Press, Princeton.

[4] Alterman, J. B. New Media, New Politics? From satellite television to the Internet inthe Arab World. The Washington Institute for Near East Policy, Washington, DC, 1998.

[5] Baasanjav, U. Mediated Political and Social Participation: Examining the Use of the Internet by Mongolian Government and Civil Society Institutions Journal of Information Technology \& Politics, 4, 3 (2008), 41-60.

[6] Borge-Holthoefer, J., Magdy, W., Darwish, K. and Weber, I. 2015. Content and network dynamics behind Egyptian political polarization on Twitter. In Proceedings of the 2015 Conference on Computer Supported Cooperative Work (CSCW'15) (Vancouver, BC, Canada, March 14-18, 2015). ACM, New York, NY, 700-711.

[7] boyd, d. and Ellison, N. Social network sites: Definition, history and scholarship. . Journal of Computer-Mediated Communication, 13, 1 (2007), article 11.

[8] Chadwick, A. 2006 Internet politics: States, citizens, and new communication technologies Oxford University Press, New York, NY.
[9] Chouikha, L. L'audiovisuel en Tunisie: Une libéralization fondue dans le moule étatique. City, 2007.

[10] Dahdal, S. Social Media and the Arab Spring: The historical context and the role of Aljazeera satellite station. Donau-Universitat Krems, City, 2012.

[11] Dahl, R. A. 1989 Democracy and its Critics. Yale University Press, New Haven, CT.

[12] Dhillon, N. and Youssef, T. Generation in Waiting: The unfulfilled promise of young people in the Middle East. Brookings Institution, City, 2009.

[13] Egel, D. and Garbouj, M. Socioeconomic drivers of the spread of the Tunisian revolution. RAND Corporation and the Graduate Institute, Geneva, Switzerland, 2013.

[14] Ghannam, J. Digital media in the Arab world one year after the revolutions. Center for International Media Assistance (CIMA), National Endowment for Democracy, Washington, DC, 2012.

[15] Ghareeb, E. New Media and the Information Revolution in the Arab World. The Middle East Journal, 54, 3 (2000), 395-418.

[16] Gunther, A., Hong, Y.-H. and Rodriguez, L. Balancing trust in media and trust in government during political change in Taiwan. Journalism Quarterly, 71, 3 (1994), 628636.

[17] Haugbølle, R. and Cavatorta, F. Beyond Ghannouchi: Islamism and social change in Tunisia. Middle East Report, 2012, Spring (2012), 20-25.

[18] Haugbølle, R. and Cavatorta, F. Vive la grande famille des médias Tunisiens: Media reform, authoritarian resilience and societal responses in Tunisia. Journal of North African Studies, 17, 1 (2012), 97-112.

[19] Honwana, A. 2013 Youth and Revolution in Tunisia. Zed Books, London.

[20] Howard, P. N. 2010 Digital Origins of Dictatorship and Democracy: The Internet and Political Islam. Oxford University Press, New York, NY.

[21] Howard, P. N. and Hussain, M. M. The Role of Digital Media. Journal of Democracy, 22, 3 (2011), 35-48.

[22] Huang, Y. L., Starbird, K., Orand, M., Stanek, S. A. and Pedersen, H. T. 2015. Connected through crisis: Emotional proximity and the spread of misinformation online. In Proceedings of the 2015 conference on Computer 
Supported Cooperative Work (Vancouver, BC, Canada, March 14-18, 2015). ACM, New York, NY, 969-980.

[23] IBRD. World Development Indicators. International Bank for Reconstruction and Development (IBRD) The World Bank, Washington, DC, 2010-2014.

[24] Kaid, L. L., McKinney, M. S. and Tedesco, J. C. Political information efficacy theory and younger voters. American Behavioral Scientist, 50 (2007), 1093-1111.

[25] Kavanaugh, A. 1998 The Social Control of Technology in North Africa: Information in the global economy Praeger, Westport.

[26] Kavanaugh, A., Sheetz, S. D., Hassan, R., Yang, S., Elmongui, H., Fox, E. A., Magdy, M. and Shoemaker, D. Between a Rock and a Cell Phone: Communication and Information Technology Use during the 2011 Uprisings in Tunisia and Egypt. International Journal of Information Systems for Crisis Response and Management, 5, 1 (2013), $1-21$.

[27] Kavanaugh, A., Sheetz, S. D., Tedesco, J. C., Sandoval-Almazan, R. and Fox, E. A. Media Use during Conflicts: Information seeking gratifications and efficacy during 2-12 Mexican elections. Government Information Quarterly, Special Isue on Smart Government, Tools and Experiences. (In Press).

[28] Kraidy, M. M. Hypermedia and Governance in Saudi Arabia. First Monday, Special Issue 7 (2006).

[29] Lotan, G., Graeff, E., Ananny, M., Gaffney, D., Pearce, I. and boyd, d. The revolutions were tweeted: Information flows during the 2011 Tunisian and Egyptian revolutions. International Journal of Communication, 5 (2011), 1375-1405.

[30] Marzouki, Y., Skandrani-Marzouki, I., Bejaoui, M., Hammoudi, H. and Bellaj, T. The contribution of Facebook to the 2011 Tunisian revolution: A cyberpsychological insight. Cyberpsychology, Behavior and Social Networking, 15,5 (2012), 237-244.

[31] Meikeljohn, A. 1948 Free Speech and its Relation to Self-Government Harper \& Brothers, New York.

[32] Michaelson, M. Political efficacy and electoral participation of Chicago Latinos. Social Science Quarterly, 81, 1 (2000), 136-150.

[33] Morgan, J. S., Shafiq, M. Z. and Lampe, C. 2013. Is news sharing on Twitter ideologically biased? In Proceedings of the 2013 Conference on Computer
Supported Cooperative Work (San Antonio, TX, USA, February 23-27, 2013). ACM, New York, NY, 887-896.

[34] Nisbet, E. C. and Myers, T. A. Anti-American sentiment as a media effect? Arab media, political identity, and public opinion in the Middle East. Communication Research, 38, 5 (2011), 684-709.

[35] Rosenberg, M. 1968 The Logic of Survey Analysis. Basic Books, Inc., New York, NY.

[36] Salem, F. and Mourtada, R. Citizen engagement and public services in the Arab world: The potential of social media. Mohammed Bin Rashid School of Government, Dubai, UAE, 2014.

[37] Shane, P. M. 2004 Democracy online: the prospects for political renewal through the Internet Routledge, New York, NY.

[38] Siebert, F. S., Peterson, T. and Schramm, W. 1963 Four Theories of the Press University of Illinois Press, Urbana, IL.

[39] Skandrani, H. and Triki, A. Trust in supply chains, meanings, determinants and demonstrations: A qualitative study in an emerging market context. Qualitative Research: An International Journal, 14, 4 (2011), 391-409.

[40] Starbird, K. and Palen, L. 2012. (How) will the revolution be retweeted? Information diffusion and the 2011 Egyptian uprising. In Proceedings of the 2012 Conference on Computer Supported Cooperative Work (CSCW'12) (Seattle, WA, February 11-13, 2012). ACM, New York, NY, 7-16.

[41] Stoll, J., Foot, K. and Edwards, W. K. Between Us and Them: Building connectedness within civic networks. ACM, City, 2012.

[42] Sudman, S. and Bradburn, N. M. 1982 Asking Questions: A practical guide to questionnaire design. Jossey-Bass, San Francisco, CA.

[43] Tufekci, Z. Social media and the decision to participate in political protest: Observations from Tahrir Square. Journal of Communication, 62, 2 (2012), 363-379.

[44] Tufekci, Z. and Freelon, D. Introduction to the Special Issue on New Media and Social Unrest. American Behavioral Scientist, 57, 7 (2013), 843-847.

[45] Verba, S. and Nie, N. H. 1972 Participation in America: political democracy and social equality. Harper \& Row, New York, NY. 
[46] Wang, Y. and Mark, G. 2013. Trust in online news: Comparing social media and official media use by Chinese citizens. In Proceedings of the 2013 Conference on Computer Supported Cooperative Work (CSCW'13) (San Antonio, TX, USA, February 23-27, 2013). ACM, New York, NY, 599-610.

[47] Wellman, B. Which ties provide what kinds of support? Advances in Group Processes, 9 (1992), 207-235.

[48] Wulf, V., Mitase, K., Atam, M., Randall, D. and Rohde, M. 2013. 'On the Ground' in Sidi Bouzid:
Investigating social media use during the Tunisian revolution. In Proceedings of the 2013 conference on Computer Supported Cooperative Work (CSCW'13) (San Antonio, Texas, USA, February 23-17, 2013, 2013). ACM Press, New York, NY, USA, 1409-1418.

[49] Zuniga, H. G. d., Jung, N. and Valenzuela, S. Social media use for news and individuals' social capital, civic engagement and political participation. Journal of Computer Mediated Communication, 17 (2012), 319-336. 